(c) American Dairy Science Association, 2003.

\title{
Effects of Corn Grain Conservation Method on Ruminal Digestion Kinetics for Lactating Dairy Cows at Two Dietary Starch Concentrations
}

\author{
M. Oba ${ }^{1}$ and M. S. Allen \\ Department of Animal Science, Michigan State University, East Lansing 48824
}

\begin{abstract}
Effects of conservation method of corn grain and dietary starch concentration on ruminal digestion kinetics were evaluated. Eight ruminally and duodenally cannulated Holstein cows ( $55 \pm 15.9$ days in milk; mean $\pm \mathrm{SD}$ ) were used in a duplicated $4 \times 4$ Latin square design with a $2 \times 2$ factorial arrangement of treatments. Experimental diets contained either ground high moisture corn (HM) or dry ground corn (DG) at two dietary starch concentrations (32 vs. $21 \%$ ). Mean particle size and dry-matter concentration of corn grain were 1863 $\mu \mathrm{m}$ and $63.2 \%$, and $885 \mu \mathrm{m}$ and $89.7 \%$, for $\mathrm{HM}$ and $\mathrm{DG}$, respectively. Starch digestibility in the rumen was greater for HM treatments compared with DG treatments, but starch digestibility in the total tract was not affected by conservation method of corn grain because of compensatory digestion in the intestines. The difference in ruminal starch digestibility between $\mathrm{HM}$ and DG treatment was greater for high-starch diets (71.1 vs. 46.9\%) compared with low-starch diets (58.5 vs. $45.9 \%$ ). This interaction is attributed to a greater difference in first-order digestion rate of starch between $\mathrm{HM}$ and DG treatment in high-starch diets $(28.2$ vs. $14.6 \% / \mathrm{h})$ compared with low-starch diets (16.8 vs. $12.2 \% / \mathrm{h})$. This suggests that ruminal starch digestion is a second-order reaction limited by enzyme activities as well as substrate availability; ruminal contents of cows fed lowstarch diets may have insufficient amylolytic activity for maximal starch digestion when readily fermentable starch is available. Rate of neutral detergent fiber digestion in the rumen was slower for high-starch diets and HM treatments compared with low-starch diets and DG treatments, respectively. Effects of corn grain conservation method on ruminal digestion kinetics are greatly altered by starch concentration of diets.
\end{abstract}

(Key words: conservation method of corn, starch digestibility, digestion kinetics)

\footnotetext{
Received March 18, 2002.

Accepted June 11, 2002.

Corresponding author: M. S. Allen; e-mail: allenm@pilot.msu.edu.

${ }^{1}$ Current address: Department of Animal and Avian Sciences, University of Maryland.
}

\begin{abstract}
Abbreviation key: $\mathbf{D G}=$ dry ground corn; $\mathbf{E E}=$ ether extract; HM = high moisture corn; PDNDF = potentially digestible NDF; TRDOM = true ruminally degraded OM.
\end{abstract}

\section{INTRODUCTION}

Starch is an important source of fuels for lactating dairy cows and for microbial protein production in the rumen. Although starch is potentially completely digestible, starch digestion is affected by a variety of factors, such as type of grain (Herrera-Saldana et al., 1990), processing method (Galyean et al., 1981; Callison et al., 2001), conservation method (Ying and Allen, 1998), and endosperm type (Rooney and Pflugfelder, 1986). Because starch in cereal grains is embedded in a protein matrix inside the endosperm, disruption of the protein matrix is required for starch digestion by microbes in the rumen (Kotarski et al., 1992). Grains vary in amount and solubility of protein in the endosperm, and substrate availability for starch digestion affects rate of starch digestion and starch digestibility in the rumen. Moreover, some processing methods gelatinize starch, increasing the rate of starch digestion. Substrate availability is an important factor affecting rate of starch digestion by ruminal microbes.

Starch digestibility could also be affected by enzyme activity of ruminal fluid. The growth rate of amylolytic bacteria was affected by type of carbohydrate in vitro, and their growth rate was faster for a medium containing starch than for a medium containing glucose (Cotta, 1988). Therefore, dietary starch concentration should affect the population of amylolytic and proteolytic microbes in the rumen and enzyme activity of ruminal fluid, which could affect rate of starch digestion. Ruminal starch digestibility is also affected by rate of starch passage from the rumen, which can be affected by conservation method and dietary starch concentration. Ying and Allen (1998) reported that the passage rate of starch for dry ground corn (DG) was much greater than for ground high-moisture corn (HM) in experiments with pregnant heifers before calving and with the same animals after calving. The objective of 
our experiment was to evaluate effects of conservation method of corn grain on ruminal digestion kinetics for cows fed diets varying in starch concentration.

\section{MATERIALS AND METHODS}

This paper is one of three papers in a series from one experiment that evaluated effects of corn grain conservation method at two dietary starch concentrations. This paper discusses treatment effects on ruminal digestion kinetics, and the companion papers focus on feeding behavior and productivity (Oba and Allen, 2003a) and efficiency of microbial nitrogen production (Oba and Allen, 2003b). Experimental procedures were approved by the All University Committee on Animal Use and Care at Michigan State University.

\section{Treatments and Cows}

Eight multiparous Holstein cows $(55 \pm 15.9$ DIM; mean \pm SD) from the Michigan State University Dairy Cattle Teaching and Research Center were randomly assigned to a treatment sequence within a duplicated $4 \times 4$ Latin square balanced for carryover effects with a $2 \times 2$ factorial arrangement of treatments. Factors evaluated were dietary starch concentration (21 vs. $32 \%$ ) and conservation method of corn grain (HM vs. DG). Treatment periods were $21 \mathrm{~d}$, with the final $10 \mathrm{~d}$ used to collect samples and data. Cows were cannulated ruminally and duodenally before calving. Duodenal cannulas were a soft gutter type made of Tygon and vinyl tubing (Crocker et al., 1998). The duodenum was fistulated between the pylorus and the pancreatic duct, and cannulas were placed between 10th and 11th ribs, as described by Robinson et al. (1985). Surgeries were performed at the Department of Large Animal Clinical Science, College of Veterinary Medicine, Michigan State University. At the beginning of the experiment, empty BW (ruminal digesta removed) of cows were $565.5 \pm 58.5 \mathrm{~kg}$ (mean $\pm \mathrm{SD}$ ).

One corn hybrid (Pioneer 3730; Pioneer Hi-bred International, Inc., Johnston, IA) was grown in 1998, and half of the field was harvested as HM at a DM concentration of $63.2 \%$. The HM was ground to mean particle size of $1863 \mu \mathrm{m}$ and ensiled in a 2.4- $\times 9.0-\mathrm{m}$ silage bag (Ag Bagger; Ag Bag Corp., Blair, NE). The remaining half of the field was harvested as dry corn at $89.7 \%$ DM. Dry corn was finely ground to a mean particle size of $885 \mu \mathrm{m}$. Nutrient composition for corn grain treatments is shown in Table 1. Experimental diets contained either HM or DG, corn silage (50\% of forage $\mathrm{DM}$ ), alfalfa silage (50\% of forage DM), a premix of protein supplements (soybean meal, distiller's grains, and blood meal), and a premix of minerals and vitamins
Table 1. Nutrient composition of corn grains used to formulate experimental diets. $^{1}$

\begin{tabular}{|c|c|c|c|}
\hline & $\mathrm{HM}^{2}$ & $\mathrm{DG}^{3}$ & $\mathrm{SE}$ \\
\hline $\mathrm{DM} \%{ }^{4}$ & 63.2 & 89.7 & 0.2 \\
\hline Starch & 67.0 & 70.5 & 1.3 \\
\hline $\mathrm{NDF}^{4}$ & 7.1 & 10.3 & 0.2 \\
\hline $\mathrm{ADF}$ & 2.4 & 3.0 & 0.2 \\
\hline Crude protein & 9.1 & 9.1 & 0.1 \\
\hline Ether extract ${ }^{5}$ & 6.3 & 7.3 & 0.2 \\
\hline $\mathrm{Ash}^{5}$ & 1.6 & 1.3 & 0.1 \\
\hline Lactate & 2.4 & - & - \\
\hline Ethanol & 0.2 & - & - \\
\hline VFA & 0.8 & - & - \\
\hline Other organic acids ${ }^{6}$ & 3.9 & - & - \\
\hline Mean particle size $(\mu \mathrm{m})^{4}$ & 1863 & 885 & 40 \\
\hline
\end{tabular}

${ }^{1}$ Nutrient composition of corn grains sampled each period $(n=4$ for each grain) were analyzed by ANOVA.

${ }^{2}$ High-moisture corn.

${ }^{3}$ Dry ground corn.

${ }^{4}$ Differed significantly between high-moisture corn and dry ground corn $(P<0.001)$.

${ }^{5}$ Differed significantly between high-moisture corn and dry ground corn $(P<0.05)$.

${ }^{6}$ Citrate, formate, malate, oxalate, and succinate.

(Table 2). All diets were formulated for $18 \%$ dietary CP concentration and fed as a TMR.

\section{Data and Sample Collection}

Throughout the experiment, cows were housed in tie stalls, and fed once daily $(1400 \mathrm{~h})$ at $110 \%$ of expected intake. The amount of feed offered and orts were weighed for each cow daily during the collection period. Samples of all dietary ingredients $(0.5 \mathrm{~kg})$ and orts $(12.5 \%)$ were collected daily and composited into one sample per cow per period. Ruminal contents were evacuated manually through the ruminal cannula at 1800 $\mathrm{h}$ (4 h after feeding) on $\mathrm{d} 19$ and at $1000 \mathrm{~h}$ ( $4 \mathrm{~h}$ before feeding) on d 21 of each period. Total ruminal content mass and volume were determined. During evacuation, $10 \%$ aliquots of digesta were separated for ease of subsampling. Aliquots were squeezed through a nylon screen (pore size: $1 \mathrm{~mm}$ ) to separate into primarily solid and liquid phases. Samples were taken from both phases for determination of pool size of digesta components in the rumen.

Chromic oxide was used as a marker to estimate nutrient digestibility in the rumen and in the total tract. Gelatin capsules (1.5 oz. Tropac Inc., Airfield, NJ) containing $5 \mathrm{~g}$ of chromic oxide and ground spelt hulls (Wiley mill, 2 mm screen; Arthur H. Thomas, Philadelphia, PA) were dosed through the rumen cannula at 0600,1400 , and $2200 \mathrm{~h}$ (total of $15 \mathrm{~g}$ of $\mathrm{Cr}_{2} \mathrm{O}_{3} / \mathrm{d}$ ) from 7 to $14 \mathrm{~d}$ with the priming dose of $3 \times$ on $\mathrm{d}$ 7. Duodenal samples $(1000 \mathrm{~g})$ and fecal samples $(500 \mathrm{~g})$ were col- 
Table 2. Ingredients and nutrient composition of experimental diets (\% of dietary DM). ${ }^{1}$

\begin{tabular}{|c|c|c|c|c|c|}
\hline & \multicolumn{2}{|c|}{ High starch } & \multicolumn{2}{|c|}{ Low starch } & \multirow[b]{2}{*}{$\mathrm{SE}$} \\
\hline & $\mathrm{HM}^{2}$ & $\mathrm{DG}^{3}$ & $\mathrm{HM}$ & DG & \\
\hline \multicolumn{6}{|l|}{ Diet ingredients } \\
\hline Dry ground corn & - & 31.6 & - & 10.8 & - \\
\hline High-moisture corn & 32.0 & - & 11.0 & - & - \\
\hline Corn silage ${ }^{4}$ & 20.8 & 20.9 & 31.8 & 32.0 & - \\
\hline Alfalfa silage ${ }^{5}$ & 22.2 & 22.3 & 34.0 & 34.1 & - \\
\hline Protein $\operatorname{mix}^{6}$ & 21.4 & 21.5 & 19.5 & 19.5 & - \\
\hline Mineral and vitamin $\operatorname{mix}^{7}$ & 3.6 & 3.7 & 3.7 & 3.6 & - \\
\hline \multicolumn{6}{|l|}{ Nutrient composition } \\
\hline $\mathrm{DM}$ & $48.8^{\mathrm{b}}$ & $53.0^{\mathrm{a}}$ & $42.8^{\mathrm{d}}$ & $43.8^{\mathrm{c}}$ & 0.2 \\
\hline $\mathrm{OM}$ & $93.4^{\mathrm{a}}$ & $93.5^{\mathrm{a}}$ & $92.2^{\mathrm{b}}$ & $92.3^{\mathrm{b}}$ & 0.1 \\
\hline Starch & $31.1^{\mathrm{a}}$ & $32.2^{\mathrm{a}}$ & $21.0^{\mathrm{b}}$ & $21.3^{\mathrm{b}}$ & 0.5 \\
\hline $\mathrm{NDF}$ & $23.1^{\mathrm{b}}$ & $24.2^{\mathrm{b}}$ & $30.1^{\mathrm{a}}$ & $30.5^{\mathrm{a}}$ & 0.2 \\
\hline $\mathrm{ADF}$ & $15.2^{\mathrm{b}}$ & $15.4^{\mathrm{b}}$ & $20.8^{\mathrm{a}}$ & $20.9^{\mathrm{a}}$ & 0.2 \\
\hline Lignin & $2.2^{\mathrm{b}}$ & $2.2^{\mathrm{b}}$ & $3.3^{\mathrm{a}}$ & $3.3^{\mathrm{a}}$ & 0.1 \\
\hline Indigestible $\mathrm{NDF}^{8}$ & $10.9^{\mathrm{b}}$ & $11.2^{\mathrm{b}}$ & $14.6^{\mathrm{a}}$ & $14.7^{\mathrm{a}}$ & 0.2 \\
\hline $\mathrm{CP}$ & 18.0 & 18.0 & 18.3 & 18.3 & 0.1 \\
\hline Ether extract & $5.2^{\mathrm{b}}$ & $5.5^{\mathrm{a}}$ & $4.8^{\mathrm{c}}$ & $4.9^{\mathrm{c}}$ & 0.1 \\
\hline Forage NDF & $16.5^{\mathrm{b}}$ & $16.5^{\mathrm{b}}$ & $25.3^{\mathrm{a}}$ & $25.4^{\mathrm{a}}$ & 0.1 \\
\hline \multirow{2}{*}{$\begin{array}{l}\text { Treatment corn grain starch } \\
\text { (\% of dietary starch) }\end{array}$} & & & & & \\
\hline & $68.8^{\mathrm{a}}$ & $69.8^{\mathrm{a}}$ & $35.0^{\circ}$ & $36.2^{b}$ & 0.6 \\
\hline
\end{tabular}

\footnotetext{
${ }^{1}$ Actual nutrient compositions of experimental diets were calculated for each period $(\mathrm{n}=4$ for each treatment) and analyzed by ANOVA. Means for nutrient composition in same row followed by different superscript letters differ significantly $(P<0.05)$.

${ }^{2}$ High-moisture corn.

${ }^{3}$ Dry ground corn.

${ }^{4}$ Concentrations of NDF and CP were 39.1 and 7.2 (\% of DM), respectively.

${ }^{5}$ Concentrations of NDF and CP were 38.2 and 19.0 (\% of DM), respectively.

${ }^{6}$ Contained $70.2 \%$ soybean meal, $26.9 \%$ distiller's grain, and $2.9 \%$ blood meal.

${ }^{7}$ Contained $50.0 \%$ dry ground corn, $15.6 \%$ sodium bicarbonate, $11.3 \%$ limestone, $10.4 \%$ dicalcium phosphate, $4.9 \%$ salt, $4.5 \%$ magnesium oxide, $2.5 \%$ trace mineral premix, and $0.85 \%$ vitamin $\mathrm{ADE}$ premix.

${ }^{8}$ Estimated after 120 -h in vitro ruminal fermentation.
}

lected every $9 \mathrm{~h}$ from 12 to $14 \mathrm{~d}$ so that eight samples were taken for each cow each period, representing every $3 \mathrm{~h}$ of a 24 -hour period to account for diurnal variation. Samples were immediately frozen at $-20^{\circ} \mathrm{C}$.

\section{Sample and Statistical Analysis}

All samples were composited to one sample per cow per period before drying. Duodenal samples were composited and separated into primarily solid and liquid phases using four layers of cheesecloth. Both phases were weighed, ratio of each phase was determined, and subsamples were taken from both phases according to the ratio determined for each sample to minimize sampling errors due to the segregation of samples into solid and liquid phases. Diet ingredients, orts, and feces were dried in a $55^{\circ} \mathrm{C}$ forced-air oven for $72 \mathrm{~h}$ and analyzed for DM concentration. Ruminal digesta and duodenal samples were lyophilized (Tri-Philizer MP; FTS Systems, Stone Ridge, NY). All samples were ground with a Wiley mill (1-mm screen; Arthur H. Thomas, Philadelphia, PA). Samples were analyzed for ash, NDF, ADF, lignin, indigestible NDF, CP, and starch. Ash concen- tration was determined after $5 \mathrm{~h}$ of oxidation at $500^{\circ} \mathrm{C}$ in a muffle furnace. Concentration of NDF and ADF were determined (method A for NDF [VanSoest et al., 1991]). Crude protein was analyzed according to Hach et al. (1987). Starch was measured by an enzymatic method (Karkalas, 1985) after samples were gelatinized with sodium hydroxide, glucose concentration was measured with glucose oxidase (Glucose kit \#510; Sigma Chemical Co., St. Louis, MO), and absorbance was determined with a micro-plate reader (SpectraMax 190; Molecular Devices Corp., Sunnyvale, CA). Indigestible NDF was estimated as NDF residue after 120$\mathrm{h}$ in vitro fermentation (Goering and VanSoest, 1970). Ruminal fluid for the in vitro incubations was collected from a nonpregnant dry cow fed alfalfa hay only. Concentrations of all nutrients except for DM were expressed as percentages of DM determined by drying at $105^{\circ} \mathrm{C}$ for more than $8 \mathrm{~h}$ in a forced-air oven. Corn grain was dry-sieved (Sieve apertures: 4750, 2360, 1180, 600, $300,150,75 \mu \mathrm{m}$ and bottom pan) with a sieve shaker (model RX-86; W. S. Tyler Inc., Gastonia, NC) for approximately 20 min until the bottom pan weight was 
constant, and mean particle size of corn grain was calculated (ASAE, 1968).

Duodenal digesta and fecal samples were analyzed for concentrations of chromium. Samples were digested with phosphoric acid (Williams et al., 1962), and chromium was quantified by flame atomic absorption spectrometry (SpectraAA 220; Varian, Victoria, Australia) according to manufacturer's recommendation. Duodenal flow of microbial OM was determined as described in a companion paper (Oba and Allen, 2003b), and true ruminally degraded OM (TRDOM) was calculated by subtracting duodenal flow of nonmicrobial OM from OM intake. Ruminal pool sizes (kg) of DM, OM, NDF, indigestible NDF, and starch were determined by multiplying the concentration of each component by the ruminal digesta DM weight (kg) except for DM. Turnover rate in the rumen, passage rate from the rumen, and ruminal digestion rate of each component $(\% / \mathrm{h})$ were calculated by the following equations:

Turnover rate in the rumen $(\% / \mathrm{h})=$

(intake of component/ruminal pool of component)/ $24 \times 100$

Passage rate from the rumen $(\% / \mathrm{h})=$

(duodenal flow of component/ruminal pool of component)/ $24 \times 100$

Digestion rate in the rumen $(\% / \mathrm{h})=$

turnover rate in the rumen $(\% / \mathrm{h})$ - passage rate from the rumen $(\% / \mathrm{h})$

All data were analyzed using the fit model procedure of JMP (version 4, SAS Institute, Cary, NC) according to the following model:

$$
\mathrm{Y}_{\mathrm{ijkl}}=\mu+\mathrm{C}_{\mathrm{i}}+\mathrm{P}_{\mathrm{j}}+\mathrm{T}_{\mathrm{k}}+\mathrm{e}_{\mathrm{ijkl}}
$$

where

$$
\begin{aligned}
\mu & =\text { overall mean, } \\
\mathrm{C}_{\mathrm{i}} & =\text { random effect of cow }(\mathrm{i}=1 \text { to } 8), \\
\mathrm{P}_{\mathrm{j}} & =\text { fixed effect of period }(\mathrm{j}=1 \text { to } 4) \\
\mathrm{T}_{\mathrm{k}} & =\text { fixed effect of treatment }(\mathrm{k}=1 \text { to } 4), \text { and } \\
\mathrm{e}_{\mathrm{ijkl}} & =\text { residual, assumed to be normally distributed. }
\end{aligned}
$$

Period $\times$ treatment interaction was originally evaluated, but it was removed from the statistical model because the interaction was not significant. Orthogonal contrasts were made for the effects of dietary starch concentration and conservation method of corn grain, and the interaction of dietary starch concentration and conservation method. Treatment effects and their interaction were declared significant at $P<0.05$ and $P<$ 0.10 , respectively, and tendency for treatment effects and their interaction were declared at $P<0.10$ and $P$ $<0.15$, respectively. When interactions of main effects were significant, treatment means were compared using Student's t-test, and differences were declared significant at $P<0.05$.

\section{RESULTS AND DISCUSSION}

\section{Site of Digestion}

Total-tract DM digestibility was greater for highstarch diets than for low-starch diets $(P<0.01$; Table $3)$ and for HM treatment than for DG treatment $(P<$ 0.05). TRDOM varied from $11.3 \mathrm{~kg} / \mathrm{d}$ for cows fed HM corn in high-starch diets to $7.7 \mathrm{~kg} / \mathrm{d}$ for cows fed DG corn in low-starch diets. The TRDOM (\% of intake) was greater for high-starch diets than for low-starch diets $(P<0.02)$ and for HM treatment than for DG treatment $(P<0.01)$, which is in agreement with previous observations (Ying et al., 1998). Although apparent digestibility of $\mathrm{OM}$ in the total tract was greater for HM than for DG treatment $(P<0.05)$, the difference in total-tract $\mathrm{OM}$ digestibility between $\mathrm{HM}$ and $\mathrm{DG}$ treatments was small compared with the treatment effect on true OM digestibility in the rumen. When cows were fed high-starch diets, HM treatment increased TRDOM by $20 \%$ compared with DG treatment (60.8 vs. $50.7 \%)$ but increased total-tract OM digestibility by only $6 \%$ (74.6 vs. $70.7 \%$ ) because of compensatory digestion in the intestines. Previous experiments also reported that compensatory digestion in the intestines occurred when cows were fed less fermentable grains (Knowlton et al., 1998; Callison et al., 2001; Ying et al., 1998).

Treatment effects on $\mathrm{OM}$ digestion in the rumen are largely explained by differences in ruminal starch digestibility because no treatment effects were observed on ruminal NDF digestibility. Starch digestibility in the rumen was greater for HM than for DG treatment $(P<0.001$; Table 4$)$, and a tendency for interaction of main effects $(P<0.13)$ indicated greater difference between HM and DG treatments in highstarch diets (71.1 vs. $46.9 \%)$ than in low-starch diets (58.5 vs. $45.9 \%)$. A significant interaction of treatments was also observed for duodenal starch flow ( $P$ $<0.01$ ), indicating greater duodenal starch flow for DG than for HM treatment when cows were fed highstarch diets (4.2 vs. $2.2 \mathrm{~kg} / \mathrm{d})$ instead of low-starch diets ( 2.4 vs. $1.9 \mathrm{~kg} / \mathrm{d})$. As starch passing to the duodenum increased, the amount of starch digested in the intestines increased linearly $\left(\mathrm{r}^{2}=0.99 ; P<0.0001\right.$; Figure 1). In addition, it is noteworthy that intestinal 
OBA AND ALLEN

Table 3. Effects of corn grain conservation method at two dietary starch concentrations on digestibility of $\mathrm{DM}$ and $\mathrm{OM}$.

\begin{tabular}{|c|c|c|c|c|c|c|c|c|}
\hline & \multicolumn{2}{|c|}{ High starch } & \multicolumn{2}{|c|}{ Low starch } & \multirow[b]{2}{*}{ SE } & \multicolumn{3}{|c|}{$P$-value } \\
\hline & $\mathrm{HM}^{1}$ & $\mathrm{DG}^{2}$ & HM & DG & & Starch $^{3}$ & Corn $^{4}$ & INT $^{5}$ \\
\hline \multicolumn{9}{|l|}{$\mathrm{DM}$} \\
\hline Intake (kg/d) & $20.8^{\mathrm{b}}$ & $22.5^{\mathrm{a}}$ & $19.7^{\mathrm{b}}$ & $19.6^{\mathrm{b}}$ & 0.5 & $<0.001$ & 0.12 & $0.07^{6}$ \\
\hline $\begin{array}{l}\text { Apparently digested in total tract } \\
(\mathrm{kg} / \mathrm{d})\end{array}$ & 14.7 & 15.1 & 130 & 126 & 05 & $<0001$ & 095 & 0.43 \\
\hline$(\%)$ & 73.3 & 69.6 & $\begin{array}{l}10.0 \\
68.6\end{array}$ & $\begin{array}{l}12.0 \\
67.1\end{array}$ & 1.3 & $<0.01$ & 0.05 & 0.32 \\
\hline \multicolumn{9}{|l|}{ OM } \\
\hline Intake (kg/d) & $18.6^{\mathrm{b}}$ & $20.2^{\mathrm{a}}$ & $17.3^{\mathrm{bc}}$ & $17.3^{\mathrm{c}}$ & 0.4 & $<0.001$ & 0.07 & 0.06 \\
\hline $\begin{array}{l}\text { Apparently digested in the rumen } \\
(\mathrm{kg} / \mathrm{d})\end{array}$ & 6.2 & 4.7 & 5.2 & 3.9 & 0.5 & 0.12 & $<0.01$ & 0.88 \\
\hline$(\%)$ & 33.5 & 23.2 & 29.1 & 22.2 & 2.7 & 0.39 & $<0.01$ & 0.59 \\
\hline $\begin{array}{l}\text { Truly digested in the rumen } \\
(\mathrm{kg} / \mathrm{d})\end{array}$ & 11.3 & 10.3 & 9.3 & 7.7 & 0.6 & $<0.001$ & 0.03 & 0.60 \\
\hline$(\%)$ & 60.8 & 50.7 & 52.6 & 44.0 & 2.7 & 0.02 & $<0.01$ & 0.82 \\
\hline Passage to duodenum $(\mathrm{kg} / \mathrm{d})$ & $12.4^{\mathrm{b}}$ & $15.6^{\mathrm{a}}$ & $12.1^{\mathrm{b}}$ & $13.4^{\mathrm{a}}$ & 0.5 & 0.03 & $<0.001$ & 0.10 \\
\hline \multicolumn{9}{|l|}{$\begin{array}{l}\text { Apparently digested in the intestines } \\
(\mathrm{kg} / \mathrm{d})\end{array}$} \\
\hline (\% of intake) & 41.1 & 47.5 & 41.0 & 46.4 & 2.9 & 0.75 & 0.05 & 0.94 \\
\hline (\% of duodenal passage) & 60.8 & 61.6 & 56.9 & 59.0 & 2.3 & 0.15 & 0.45 & 0.67 \\
\hline \multicolumn{9}{|l|}{ Apparently digested in total tract } \\
\hline$(\%)$ & 74.6 & 70.7 & 70.0 & 68.6 & 1.3 & $<0.01$ & 0.05 & 0.26 \\
\hline
\end{tabular}

${ }^{1}$ High-moisture corn.

${ }^{2}$ Dry ground corn.

${ }^{3}$ Effect of dietary starch concentration.

${ }^{4}$ Effect of conservation method of corn grain.

${ }^{5}$ Interaction of dietary starch concentration and conservation method of corn grain.

${ }^{6}$ Student's t-test was conducted if $P<0.10$ for interactions of main effects. Treatment means in same row followed by different superscript letters differ significantly $(P<0.05)$.

Table 4. Effects of corn grain conservation method at two dietary starch concentrations on digestibility of starch.

\begin{tabular}{|c|c|c|c|c|c|c|c|c|}
\hline & \multicolumn{2}{|c|}{ High starch } & \multicolumn{2}{|c|}{ Low starch } & \multirow[b]{2}{*}{$\mathrm{SE}$} & \multicolumn{3}{|c|}{$P$-value } \\
\hline & $\mathrm{HM}^{1}$ & $\mathrm{DG}^{2}$ & $\mathrm{HM}$ & DG & & Starch $^{3}$ & Corn $^{4}$ & $\mathrm{INT}^{5}$ \\
\hline \multicolumn{9}{|l|}{ Starch } \\
\hline Intake $(\mathrm{kg} / \mathrm{d})$ & $6.2^{\mathrm{b}}$ & $7.0^{\mathrm{a}}$ & $3.9^{\mathrm{c}}$ & $4.1^{\mathrm{c}}$ & 0.1 & $<0.001$ & $<0.001$ & $<0.01^{6}$ \\
\hline \multicolumn{9}{|l|}{ Digested in the rumen } \\
\hline$(\mathrm{kg} / \mathrm{d})$ & 4.3 & 3.3 & 2.4 & 1.9 & 0.2 & $<0.001$ & $<0.001$ & 0.14 \\
\hline$(\%)$ & 71.1 & 46.9 & 58.5 & 45.9 & 3.5 & 0.08 & $<0.001$ & 0.13 \\
\hline Passage to duodenum $(\mathrm{kg} / \mathrm{d})$ & $2.2^{\mathrm{b}}$ & $4.2^{\mathrm{a}}$ & $1.9^{\mathrm{b}}$ & $2.4^{\mathrm{b}}$ & 0.2 & $<0.001$ & $<0.001$ & $<0.01$ \\
\hline \multicolumn{9}{|l|}{ Digested in the intestines } \\
\hline$(\mathrm{kg} / \mathrm{d})$ & $1.9^{\mathrm{b}}$ & $3.8^{\mathrm{a}}$ & $1.6^{\mathrm{b}}$ & $2.2^{\mathrm{b}}$ & 0.2 & $<0.001$ & $<0.001$ & 0.02 \\
\hline (\% of intak & 30.5 & 53.6 & 41.1 & 53.4 & 3.7 & 0.21 & $<0.001$ & 0.19 \\
\hline (\% of duodenal passage) & 86.2 & 89.6 & 83.8 & 86.9 & 1.7 & 0.13 & 0.06 & 0.99 \\
\hline \multicolumn{9}{|l|}{ Digested in total tract } \\
\hline$(\mathrm{kg} / \mathrm{d})$ & $5.9^{\mathrm{b}}$ & $6.6^{\mathrm{a}}$ & $3.7^{\mathrm{c}}$ & $3.8^{\mathrm{c}}$ & 0.1 & $<0.001$ & $<0.01$ & 0.02 \\
\hline$(\%)$ & 95.8 & 94.2 & 93.3 & 93.0 & 0.6 & $<0.01$ & 0.16 & 0.26 \\
\hline
\end{tabular}

${ }^{1}$ High-moisture corn.

${ }^{2}$ Dry ground corn.

${ }^{3}$ Effect of dietary starch concentration.

${ }^{4}$ Effect of conservation method of corn grain.

${ }^{5}$ Interaction of dietary starch concentration and conservation method of corn grain.

${ }^{6}$ Student's t-test was conducted if $P<0.10$ for interactions of main effects. Treatment means in same row followed by different superscript letters differ significantly $(P<0.05)$. 


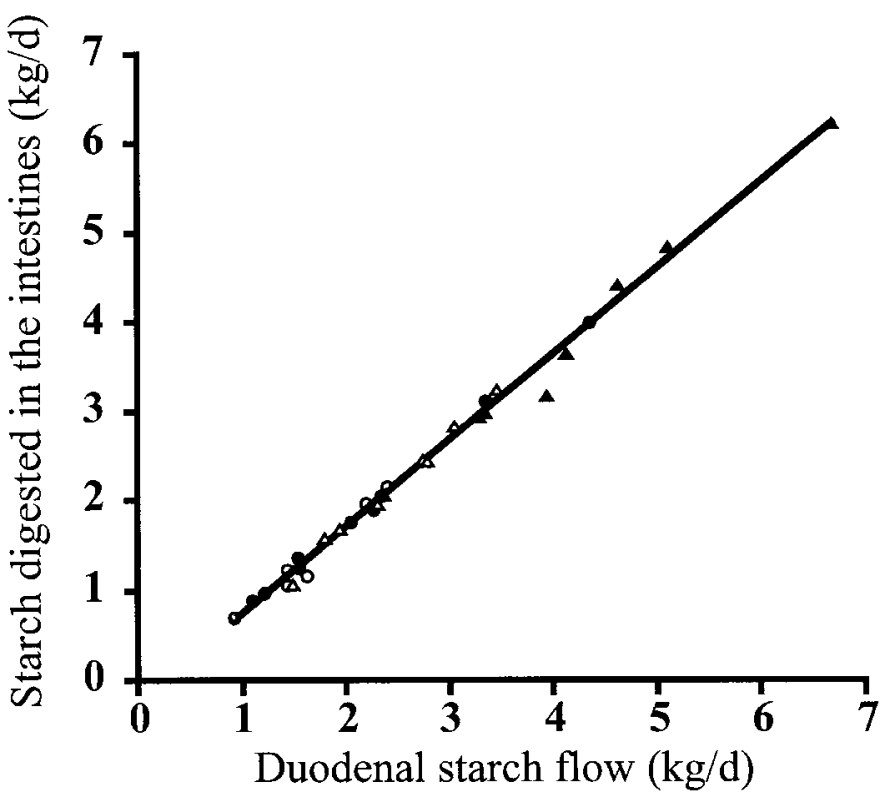

Figure 1. Relationship between duodenal starch flow (kg/d) and starch digested in the intestines $(\mathrm{kg} / \mathrm{d})$. Starch digested in the intestines $(\mathrm{kg} / \mathrm{d})=-0.22+0.97 \times$ duodenal starch flow $\left(\mathrm{r}^{2}=0.99 ; P<\right.$ 0.0001). Closed circle denotes high-moisture corn in high-starch diets, closed triangle denotes dry ground corn in high-starch diets, open circle denotes high-moisture corn in low-starch diets, and open triangle denotes dry ground corn in low-starch diets.

starch digestibility (\% of duodenal flow) increased quadratically as duodenal starch flow increased $\left(\mathrm{r}^{2}=0.49\right.$; $P<0.05 ;$ Figure 2). If enzyme activity limits maximum intestinal starch digestion, starch digestibility in the intestines would decrease as starch passing to the duodenum increased. However, lower intestinal starch digestibility associated with lower duodenal flow of starch in this experiment suggests that intestinal starch digestion was not limited by enzyme activity but instead by physical or chemical characteristics of dietary starch escaping digestion in the rumen.

Although dairy cows have high capacity for intestinal starch digestion, starch digestibility in the small intestine for lactating dairy cows fed DG is extremely variable, ranging from less than $10 \%$ (Knowlton et al., 1998) to more than $60 \%$ (Callison et al., 2001) of duodenal flow. The relative contribution of starch digested and absorbed as glucose in the small intestine or fermented to VFA in the large intestine to intestinal digestibility cannot be determined in this experiment because we did not use ileally cannulated cows. It is important to understand factors that limit maximum starch digestibility in the small intestine, because starch digestion with absorption of glucose in the small intestine is energetically more efficient than starch fermentation to VFA (Owens, 1986). Although pancreatic amylase activity may be a factor limiting maxi- mum starch digestion in the small intestine (Harmon, 1991; Huntington, 1997), more research is needed regarding differences in the digestion characteristics of starch flowing to the intestines for different starch sources and feeding conditions.

Intestinal starch digestibility (\% of intake) was greater for DG than for HM treatment, and total-tract starch digestibility was not affected by corn grain treatment in this experiment. The DG treatment resulted in a greater amount of starch digestion in the intestines than in the rumen, whereas the reverse was true for HM treatment. Greater DMI for cows fed DG compared with HM in high-starch diets, along with compensatory intestinal starch digestion, increased the amount of starch digested in the total tract $(P<$ 0.01 ) and enhanced productivity (Oba and Allen, 2003a).

\section{Starch Digestion Kinetics}

Rate of starch passage tended to be greater for DG than for HM treatment $(P=0.07$; Table 5$)$, which is consistent with observations of Ying and Allen (1998). This may be because of greater DMI for DG than for HM treatment in high-starch diets (22.5 vs. $20.8 \mathrm{~kg} /$ d) or because of differences in physical characteristics

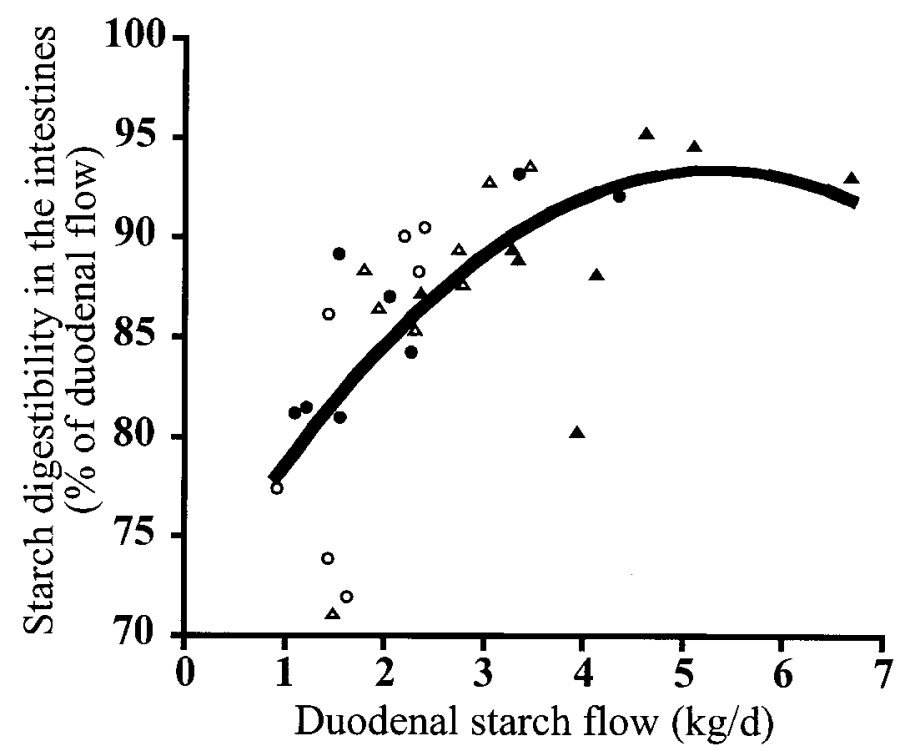

Figure 2. Relationship between duodenal starch flow $(\mathrm{kg} / \mathrm{d})$ and starch digested in the intestines (\% of duodenal flow). Starch digested in the intestines (\% of duodenal flow) $=76.5+4.23 \times$ duodenal starch flow $-0.80 \times(\text { duodenal starch flow }-2.67)^{2}\left(\mathrm{r}^{2}=0.49\right.$; linear effect $P<0.0001$; quadratic effect $P<0.05$ ). Closed circle denotes highmoisture corn in high-starch diets, closed triangle denotes dry ground corn in high-starch diets, open circle denotes high-moisture corn in low-starch diets, and open triangle denotes dry ground corn in lowstarch diets. 
Table 5. Effects of corn grain conservation method at two dietary starch concentrations on digestion kinetics in the rumen.

\begin{tabular}{|c|c|c|c|c|c|c|c|c|}
\hline & \multicolumn{2}{|c|}{ High starch } & \multicolumn{2}{|c|}{ Low starch } & \multirow[b]{2}{*}{$\mathrm{SE}$} & \multicolumn{3}{|c|}{$P$-value } \\
\hline & $\mathrm{HM}^{1}$ & $\mathrm{DG}^{2}$ & $\mathrm{HM}$ & DG & & $\mathrm{Starch}^{3}$ & Corn $^{4}$ & $\mathrm{INT}^{5}$ \\
\hline \multicolumn{9}{|l|}{ Ruminal digestion rate $(\% / \mathrm{h})$} \\
\hline Starch & $28.2^{\mathrm{a}}$ & $14.6^{\mathrm{bc}}$ & $16.8^{\mathrm{b}}$ & $12.2^{\mathrm{c}}$ & 1.2 & $<0.001$ & $<0.001$ & $<0.01^{6}$ \\
\hline Potentially digestible NDF & 2.25 & 2.91 & 3.15 & 3.44 & 0.23 & $<0.01$ & 0.05 & 0.44 \\
\hline \multicolumn{9}{|l|}{ Ruminal passage rate $(\% / \mathrm{h})$} \\
\hline $\mathrm{OM}$ & 3.98 & 5.04 & 4.05 & 5.11 & 0.32 & 0.88 & $<0.01$ & 0.94 \\
\hline Starch & 16.8 & 21.2 & 13.9 & 18.2 & 2.3 & 0.20 & 0.07 & 0.95 \\
\hline $\mathrm{NDF}$ & 3.27 & 3.61 & 3.48 & 3.87 & 0.22 & 0.31 & 0.11 & 0.89 \\
\hline Potentially digestible NDF & 2.59 & 3.01 & 2.84 & 2.67 & 0.33 & 0.84 & 0.67 & 0.41 \\
\hline Indigestible NDF & 3.33 & 3.58 & 3.38 & 3.71 & 0.22 & 0.16 & 0.03 & 0.29 \\
\hline \multicolumn{9}{|l|}{ Ruminal digesta mass (kg) } \\
\hline Wet matter & 72.4 & 75.0 & 82.1 & 78.7 & 5.2 & 0.02 & 0.90 & 0.28 \\
\hline $\mathrm{DM}$ & 8.8 & 9.6 & 9.5 & 9.3 & 0.5 & 0.61 & 0.38 & 0.19 \\
\hline $\mathrm{OM}$ & 7.9 & 8.6 & 8.4 & 8.0 & 0.4 & 0.92 & 0.66 & 0.13 \\
\hline Starch & $0.6^{\mathrm{b}}$ & $0.9^{\mathrm{a}}$ & $0.6^{\mathrm{b}}$ & $0.6^{\mathrm{b}}$ & 0.1 & $<0.01$ & $<0.01$ & $<0.01$ \\
\hline $\mathrm{NDF}$ & 4.9 & 5.0 & 5.4 & 5.2 & 0.3 & 0.16 & 0.69 & 0.43 \\
\hline Potentially digestible NDF & 2.2 & 2.1 & 2.0 & 2.0 & 0.2 & 0.25 & 0.65 & 0.55 \\
\hline Indigestible NDF & $2.7^{\mathrm{c}}$ & $2.9^{\mathrm{bc}}$ & $3.4^{\mathrm{a}}$ & $3.2^{\mathrm{ab}}$ & 0.2 & $<0.01$ & 0.85 & 0.08 \\
\hline
\end{tabular}

${ }^{1}$ High-moisture corn.

${ }^{2}$ Dry ground corn.

${ }^{3}$ Effect of dietary starch concentration.

${ }^{4}$ Effect of conservation method of corn grain.

${ }^{5}$ Interaction of dietary starch concentration and conservation method of corn grain.

${ }^{6}$ Student's t-test was conducted if $P<0.10$ for interactions of main effects. Treatment means in same row followed by different superscript letters differ significantly $(P<0.05)$.

between HM and DG. A significant interaction of dietary starch concentration and conservation method of corn grain was observed for rate of starch digestion $(P<0.01)$. Rate of starch digestion was $93 \%$ greater for HM than for DG treatment for cows fed high-starch diets $(28.2$ vs. $14.6 \% / \mathrm{h})$, but $38 \%$ greater for HM than for DG treatment for cows fed low-starch diets (16.8 vs. $12.2 \% / \mathrm{h}$ ). Corn grain treatments supplied approximately 70 and $35 \%$ of dietary starch for high- and lowstarch diets, respectively. Therefore, greater effects of corn grain treatment on rate of starch digestion for high-starch diets compared with low-starch diets were at least partially because of the different proportion of dietary starch derived from corn grain for diets varying in starch concentration. However, greater dietary allocation of treatment corn grain in high-starch diets cannot totally account for the greater difference in digestion rate between $\mathrm{HM}$ and DG treatments for high-starch diets. Digestion rate of starch differed by 4.6 units between HM and DG treatments in lowstarch diets, and high-starch diets contained approximately twice as much dietary starch from treatment corn grains compared with low-starch diets. Thus, digestion rates are expected to differ by 9.2 units between HM and DG treatments in high-starch diets, but observed digestion rate of starch differed by 13.6 units in this experiment.
A possible explanation for greater effect of corn grain treatment on digestion rate for high-starch diets compared with low-starch diets is bias caused by the onepool model used to calculate rate of digestion. Actual digestion kinetics of starch may have two or more pools of dietary starch (starch from treatment corn grains and starch from other dietary sources) with different rates of passage and digestion for each pool. We estimated rate of digestion by subtracting passage rate from turnover rate using the pool and efflux method. Therefore, bias in calculation of passage rate of starch could affect estimated digestion rate of starch, as underestimation of passage rate results in overestimation of digestion rate. However, our observation in this experiment cannot be attributed to bias caused by passage for the one-pool model. When we calculate rate of digestion, we assumed the same passage rate for all starch sources by using an overall passage rate for dietary starch. This likely led to an underestimation of passage rates of starch from the corn grain treatments and an overestimation of passage rates of starch for the other dietary sources, because rate of passage is expected to be greater for treatment corn grains than for other dietary starch sources. Treatment corn grains were finely ground and had smaller particle size than corn silage, the primary starch source among the other diet ingredients. This bias is expected to be greater 
for diets containing DG than for diets containing HM because of the tendency for greater passage rate of starch for DG treatment $(P<0.07)$ and could result in overestimation of digestion rate for diets containing DG to a greater extent than diets containing HM. In addition, the extent of overestimation in digestion rate of starch in DG treatment compared with HM treatment should be greater for high-starch diets than for low-starch diets because treatment starch is included twice as much in high-starch diets as in low-starch diets. Therefore, bias caused by the one-pool model is expected to shrink the treatment effect of corn grain on digestion rate of starch for high-starch diets compared with low-starch diets, not exaggerate it. Contrarily, we observed greater difference in digestion rate of starch for high-starch diets, and our results warrant another explanation.

The pool and flux method used for calculating rate of starch digestion in this experiment assumes firstorder kinetics and no lag phase (Ying and Allen, 1998). However, increased rate of starch digestion for HM relative to DG treatment in high-starch diets may be because ruminal starch digestion follows second-order kinetics, and high-starch diets increased microbial amylolytic activity compared with low-starch diets. Type of carbohydrate affected growth rate of amylolytic bacteria, such as Streptococcus bovis, Ruminobacter amylophilus, Butyrivibrio fibrisolvens, and Bacteroides ruminicola (Cotta, 1988). Although substrate availability was potentially increased for HM compared with DG, regardless of dietary starch concentration, maximum rate of starch digestion might have been limited to a greater extent by enzyme activity of ruminal fluid when cows were fed low-starch diets. Simultaneous equations were developed to identify effects of dietary starch concentration on relative difference in enzyme activity for starch digestion. These equations assume that rate of starch digestion is a function of enzyme activity and potential rate of digestion is determined by substrate availability:

$$
\begin{aligned}
& 28.2 \% / \mathrm{h}=\mathrm{a} \cdot\left(0.7 \cdot \mathrm{k}_{\mathrm{d}} \mathbf{H M}+0.3 \cdot \mathrm{k}_{\mathrm{d}} \mathbf{X}\right) \\
& 14.6 \% / \mathrm{h}=\mathrm{a} \cdot\left(0.7 \cdot \mathrm{k}_{\mathrm{d}} \mathbf{D G}+0.3 \cdot \mathrm{k}_{\mathrm{d}} \mathbf{X}\right) \\
& 16.8 \% / \mathrm{h}=\mathrm{b} \cdot\left(0.35 \cdot \mathrm{k}_{\mathrm{d}} \mathbf{H M}+0.65 \cdot \mathrm{k}_{\mathrm{d}} \mathbf{Y}\right) \\
& 12.2 \% / \mathrm{h}=\mathrm{b} \cdot\left(0.35 \cdot \mathrm{k}_{\mathrm{d}} \mathbf{D G}+0.65 \cdot \mathrm{k}_{\mathrm{d}} \mathbf{Y}\right)
\end{aligned}
$$

where

$$
\begin{aligned}
\mathrm{a}= & \text { enzyme activity for high-starch diets } \\
\mathrm{b}= & \text { enzyme activity for low-starch diets } \\
\mathrm{k}_{\mathrm{d}} \mathbf{H M}= & \text { rate of digestion for HM corn starch, } \\
\mathbf{k}_{\mathrm{d}} \mathbf{D G}= & \text { rate of digestion for DG corn starch, } \\
\mathbf{k}_{\mathrm{d}} \mathbf{X}= & \text { rate of digestion for other dietary starch } \\
& \text { in high-starch diets, and }
\end{aligned}
$$
$\begin{aligned} \mathrm{k}_{\mathrm{d}} \mathbf{Y}= & \text { rate of digestion for other dietary starch } \\ & \text { in low starch diets. }\end{aligned}$

This set of equations cannot be solved for specific values for coefficients a and $b$, but it can be solved for the relative relationship between coefficients a and $b$, which is 1.00:0.68, indicating that the enzyme activity for low-starch diets was $68 \%$ of that for high-starch diets. This calculation result should not be interpreted to mean that rate of starch digestion is maximized for the high-starch diets, but rather that enzyme activity can differ significantly for high- and low-starch diets. This finding has implications for models of rumen function. The CNCPS model (Sniffen et al., 1992) assumes first-order kinetics for digestion of nutrients and used constant digestion rate for the B1 fraction of carbohydrate (starch) to calculate ruminal starch digestibility regardless of dietary starch concentration. One interpretation of our data is that rate of starch digestion in the rumen follows second-order kinetics depending on both substrate availability and enzyme activity in the rumen.

\section{NDF Digestion Kinetics}

Digestion rate for potentially digestible NDF (PDNDF) decreased by 22\% for high-starch diets compared with low-starch diets $(2.58$ vs. $3.30 \% / \mathrm{h} ; P<0.01)$ and by $15 \%$ for HM compared to DG treatments $(2.70$ vs. $3.18 \% / \mathrm{h} ; P<0.05)$. Despite significant treatment effects on digestion rate for PDNDF, treatment effects on ruminal NDF digestibility and total-tract NDF digestibility were not observed, possibly because of differences in passage rate for NDF. Grant and Mertens (1992) showed that rate of NDF digestion in vitro is adversely affected by low $\mathrm{pH}$ and presence of starch. Slower rate of PDNDF digestion for high-starch diets compared with low-starch diets in this experiment can be attributed to lower ruminal $\mathrm{pH}$ (Oba and Allen, 2003b). A positive relationship was observed for daily mean ruminal $\mathrm{pH}$ and digestion rate for PDNDF (Figure $3 ; P<0.001 ; \mathrm{r}^{2}=0.34$ ). However, response variables related to ruminal $\mathrm{pH}$ (daily mean, variance, daily minimum, time under $\mathrm{pH} \mathrm{6.0,} \mathrm{and} \mathrm{area} \mathrm{under} \mathrm{pH} 6.0$ ) were not affected by corn grain treatment (Oba and Allen, 2003b). Moreover, the relationship between digestion rate for PDNDF and amount of ruminally degraded starch was not significant $\left(P>0.15 ; \mathrm{r}^{2}=0.07\right)$.

Apparent NDF digestibility either in the rumen or in the total tract was not affected by treatment (Table 6). Apparent NDF digestibility in the rumen was low for all treatments-averaging $18 \%$ of intake-which is less than $50 \%$ of apparent NDF digestibility in the total tract. Although low ruminal NDF digestibility 


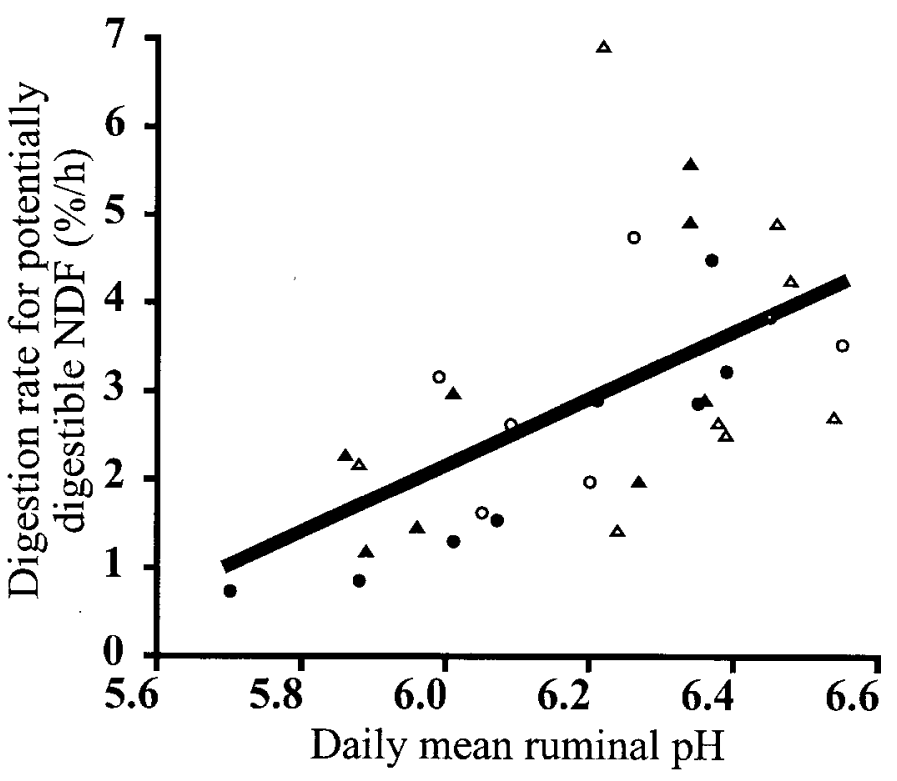

Figure 3. Relationship between daily mean ruminal $\mathrm{pH}$ and digestion rate for potentially digestible $\mathrm{NDF}(\% / \mathrm{h})$. Digestion rate for potentially digestible $\mathrm{NDF}=-20.5+3.78 \times$ daily mean ruminal $\mathrm{pH}\left(\mathrm{r}^{2}=\right.$ 0.34; $P<0.001$ ). Closed circle denotes high-moisture corn in highstarch diets, closed triangle denotes dry ground corn in high-starch diets, open circle denotes high moisture corn in low-starch diets, and open triangle denotes dry ground corn in low-starch diets.

can be attributed to low ruminal $\mathrm{pH}$ or presence of starch for high-starch diets (Grant and Mertens, 1992), reasons for similar ruminal NDF digestibility for low-starch diets are not known. Although we used higher-yielding cows, averaging more than $36 \mathrm{~kg} / \mathrm{d}$ of milk yield in this experiment (Oba and Allen, 2003a), compared with some other experiments using duodenal cannulated cows reported in the literature, DMI and passage rate of NDF were not distinguishably high for this experiment. Therefore, duodenal flow of NDF might be overestimated for this experiment, resulting in relatively lower ruminal NDF digestibility as compared with other studies in the literature.

\section{TDN Discount}

In this experiment, we showed that lactating cows have high capacity for starch digestion in the intestines and that greater amylolytic enzyme activity may enhance digestion rate for starch. These observations are not consistent with the calculation method for energy concentration of feeds used by NRC (2001). In NRC (2001), energy concentrations of diets are discounted as DMI increases above that required for maintenance, and the discount coefficient increases as TDN concentration of diets increases. Greater DMI reduces digestibility by increasing passage rate of digesta, and an intake-dependent reduction in digestibility is typically seen for dietary NDF because NDF ferments slowly in the rumen. However, greater DMI may not reduce starch digestibility to a similar extent because starch ferments rapidly in the rumen, and extensive intestinal starch digestion compensates for lower ruminal starch digestibility, as shown in this experiment. In a previous study, a treatment that in-

Table 6. Effects of corn grain conservation method at two dietary starch concentrations on digestibility of NDF.

\begin{tabular}{|c|c|c|c|c|c|c|c|c|}
\hline & \multicolumn{2}{|c|}{ High starch } & \multicolumn{2}{|c|}{ Low starch } & \multirow[b]{2}{*}{$\mathrm{SE}$} & \multicolumn{3}{|c|}{$P$-value } \\
\hline & $\mathrm{HM}^{1}$ & $\mathrm{DG}^{2}$ & $\mathrm{HM}$ & DG & & Starch $^{3}$ & Corn ${ }^{4}$ & INT $^{5}$ \\
\hline \multicolumn{9}{|l|}{$\mathrm{NDF}$} \\
\hline Intake $(\mathrm{kg} / \mathrm{d})$ & $4.6^{\mathrm{c}}$ & $5.2^{\mathrm{b}}$ & $5.5^{\mathrm{a}}$ & $5.6^{\mathrm{a}}$ & 0.1 & $<0.001$ & 0.03 & $0.04^{6}$ \\
\hline $\begin{array}{l}\text { Digested in the rumen } \\
(\mathrm{kg} / \mathrm{d}) \\
(\%)\end{array}$ & $\begin{array}{r}0.8 \\
17.2\end{array}$ & $\begin{array}{r}1.0 \\
19.4\end{array}$ & $\begin{array}{r}1.1 \\
18.6\end{array}$ & $\begin{array}{r}1.0 \\
16.6\end{array}$ & $\begin{array}{l}0.2 \\
3.0\end{array}$ & $\begin{array}{l}0.51 \\
0.82\end{array}$ & $\begin{array}{l}0.70 \\
0.97\end{array}$ & $\begin{array}{l}0.35 \\
0.50\end{array}$ \\
\hline Passage to duodenum $(\mathrm{kg} / \mathrm{d})$ & 3.8 & 4.2 & 4.5 & 4.6 & 0.2 & $<0.01$ & 0.14 & 0.44 \\
\hline \multicolumn{9}{|l|}{ Digested in the intestines } \\
\hline$(\mathrm{kg} / \mathrm{d})$ & 0.9 & 0.8 & 1.2 & 1.2 & 0.2 & 0.19 & 0.82 & 0.75 \\
\hline (\% of intake) & 20.3 & 15.8 & 20.7 & 21.6 & 4.0 & 0.46 & 0.66 & 0.50 \\
\hline (\% of duodenal passage) & 23.1 & 18.6 & 25.0 & 25.1 & 4.4 & 0.36 & 0.64 & 0.59 \\
\hline \multicolumn{9}{|l|}{ Digested in total tract } \\
\hline$(\mathrm{kg} / \mathrm{d})$ & 1.7 & 1.8 & 2.2 & 2.2 & 0.2 & 0.05 & 0.95 & 0.64 \\
\hline$(\%)$ & 37.5 & 35.2 & 39.3 & 38.2 & 3.0 & 0.46 & 0.60 & 0.80 \\
\hline
\end{tabular}

${ }^{1}$ High-moisture corn.

${ }^{2}$ Dry ground corn.

${ }^{3}$ Effect of dietary starch concentration.

${ }^{4}$ Effect of conservation method of corn grain.

${ }^{5}$ Interaction of dietary starch concentration and conservation method of corn grain.

${ }^{6}$ Student's t-test was conducted if $P<0.10$ for interactions of main effects. Treatment means in same row followed by different superscript letters differ significantly $(P<0.05)$. 
creased DMI decreased total-tract NDF digestibility but did not affect total-tract starch digestibility within a cow (Oba and Allen, 1999). Greater digestibility discounts for high-TDN diets (NRC, 2001) may be justified by their potential adverse effects on NDF digestion. In this experiment, we observed that digestion rate for PDNDF was slower for high-starch diets than for low-starch diets and for HM compared with DG treatment. However, it may not be appropriate to discount starch digestibility with a greater discount coefficient for high-TDN diets. As discussed previously, we found a greater rate of starch digestion in the rumen for HM compared with DG treatment when cows were fed high-starch diets rather than low-starch diets. In addition, total-tract starch digestibility was increased $\sim 2 \%$ by feeding high-starch diets instead of low-starch diets in this experiment $(95.0$ vs. $93.2 \% ; P<0.01)$ despite greater DMI for high-starch diets than for lowstarch diets (21.7 vs. $19.7 \mathrm{~kg} / \mathrm{d} ; P<0.001)$. Starch digestion was not adversely affected, but rather, enhanced by high-starch diets that contained greater TDN.

NRC (2001) suggested that diets with high digestibility at maintenance exhibit a greater depression in digestibility as DMI increases, compared with diets with low digestibility fed at maintenance, based on data from experiments in the literature. However, the experiments on which the regression equation is based used different cows to represent several DMI levels. Therefore, the DMI effect on nutrient digestibility is confounded by cow effect, which makes interpretation of the data more difficult. The calculation method for energy concentration of feeds in NRC (2001) uses the same discount coefficient for all nutrient components in a diet, and the discount coefficients are greater for high TDN diets regardless of nutrient components of feeds. Our data in this experiment support the idea that greater coefficients for high-TDN diets should not be used for discounting starch digestibility.

\section{CONCLUSIONS}

Substitution of DG for HM decreased starch digestibility in the rumen without affecting starch digestibility in the total tract, shifting the primary site of starch digestion from the rumen to the intestines. The HM treatment increased rate of starch digestion, compared with DG treatment, to a greater extent when cows were fed high-starch diets instead of low-starch diets. A possible explanation for our observation is that ruminal starch digestion is limited by enzyme activity as well as substrate availability; ruminal contents of cows fed low-starch diets may have insufficient amylolytic activity for maximal starch digestion when readily fermentable starch is available. Effect of corn grain conservation method on nutrient digestion is greatly altered by concentration of dietary starch.

\section{ACKNOWLEDGMENTS}

Acknowledgment is made to the Corn Marketing Program of Michigan and the Michigan Agricultural Experiment Station for financial support of this research. The authors thank N. K. Ames for performing duodenal and ruminal cannulation surgery and R. E. Kreft, R. A. Longuski, D. G. Main, C. S. Mooney, R. J. Tempelman, and Y. Ying for technical assistance.

\section{REFERENCES}

ASAE. 1968. Method of determining and expressing fineness of feed material by sieving. ASAE standard S319. St. Joseph, MI.

Callison, S. L., J. L. Firkins, M. L. Eastridge, and B. L. Hull. 2001. Site of nutrient digestion by dairy cows fed corn of different particle sizes or steam-rolled. J. Dairy Sci. 84:1458-1467.

Cotta, M. A. 1988. Amylolytic activity of selected species of ruminal bacteria. Appl. Environ. Microbiol. 54:772-776.

Crocker, L. M., E. J. DePeters, J. G. Fadel, H. Prez-Monti, S. J. Taylor, J. A. Wyckoff, and R. A. Zinn. 1998. Influence of processed corn grain in diets of dairy cows on digestion of nutrients and milk composition. J. Dairy Sci. 81:2394-2407.

Galyean, M. L., D. G. Wagner, and F. N. Owens. 1981. Dry matter and starch disappearance of corn and sorghum as influenced by particle size and processing. J. Dairy Sci. 64:1804-1812.

Goering, H. K., and P. J. Van Soest. 1970. Forage Fiber Analysis (Apparatus, Reagents, Procedures, and Some Applications). Agric. Handbook No. 379. ARS-USDA, Washington, DC.

Grant, R. J., and D. R. Mertens. 1992. Influence of buffer $\mathrm{pH}$ and raw corn starch addition on in vitro fiber digestion kinetics. J. Dairy Sci. 75:2762-2768.

Hach, C. C., B. K. Bowden, A. B. Lopelove, and S. V. Brayton. 1987. More powerful peroxide Kjeldahl digestion method. J. AOAC 70:783-787.

Harmon, D. L. 1991. Dietary influences on carbohydrases and small intestinal starch hydrolysis capacity in ruminants. J. Nutr. 122:203-210.

Herrera-Saldana, R. E., J. T. Huber, M. H. Poore. 1990. Dry matter, crude protein, and starch degradability of five cereal grains. J. Dairy Sci. 73:2386-2393.

Huntington, G. B. 1997. Starch utilization by ruminants: From basics to the bunk. J. Anim. Sci. 75:852-867.

Karkalas, J. 1985. An improved enzymatic method for the determination of native and modified starch. J. Sci. Food Agric. 36:1019-1027.

Knowlton, K. F., B. P. Glenn, and R. A. Erdman. 1998. Performance, ruminal fermentation, and site of starch digestion in early lactation cows fed corn grain harvested and processed differently. J. Dairy Sci. 91:1972-1984.

Kotarski, S. F., R. D. Waniska, and K. K. Thurn. 1992. Starch hydrolysis by the ruminal microflora. J. Nutr. 122:178-190.

National Research Council. 2001. Nutrient Requirements of Dairy Cattle. 7th rev. ed. Natl. Acad. Sci., Washington, DC.

Oba, M., and M. S. Allen. 1999. Effects of brown midrib 3 mutation in corn silage on dry matter intake and productivity of high yielding cows. J. Dairy Sci. 82:135-142.

Oba, M., and M. S. Allen. 2003a. Effects of corn grain conservation method on feeding behavior and productivity of lactating dairy cows at two dietary starch concentrations. J. Dairy Sci. $86: 174-183$

Oba, M., and M. S. Allen. 2003b. Effects of diet fermentability on efficiency of microbial nitrogen production in lactating dairy cows. J. Dairy Sci. 86:195-207. 
Owens, F. N., R. A. Zinn, and Y. K. Kim. 1986. Limits to starch digestion in the ruminant small intestine. J. Anim. Sci. 63:1634-1648.

Robinson, P. H., C. J. Sniffen, and D. F. Smith. 1985. Development of a one-piece reentrant cannula for the proximal duodenum of dairy cows. J. Dairy Sci. 68:986-995.

Rooney, L. W., and R. L. Pflugfelder. 1986. Factors affecting starch digestibility with special emphasis on sorghum and corn. J. Anim. Sci. 63:1607-1623.

Sniffen, C. J., J. D. O'Connor, P. J. Van Soest, D. G. Fox, and J. B. Russell. 1992. A net carbohydrate and protein system for evaluating cattle diets. II. Carbohydrate and protein availability. J. Anim. Sci. 70:3562-3577.

Van Soest, P. J., J. B. Robertson, and B. A. Lewis. 1991. Methods for dietary fiber, neutral detergent fiber and nonstarch polysac- charides in relation to animal nutrition. J. Dairy Sci. 74:3583-3597.

Williams, C. H., D. J. David, and O. Iismaa. 1962. The determination of chromic oxide in feces samples by atomic absorption spectrophotometry. J. Agric. Sci. 59:381-385.

Ying, Y., and M. S. Allen. 1998. Effects of fineness of grinding and conservation method of corn grain on ruminal starch digestion kinetics in Holstein heifers before and after calving. J. Dairy Sci. 81(Suppl. 1):318.

Ying, Y., M. S. Allen, M. J. VandeHaar, and N. K. Ames. 1998. Effects of fineness of grinding and conservation method of corn grain on ruminal and whole tract digestibilities and ruminal microbial protein production of Holstein cows in early lactation. J. Dairy Sci. 81(Suppl. 1):339. 